\title{
Manganese influences the expression of fatty acid synthase and malic enzyme in cultured primary chicken hepatocytes
}

\author{
Lin Lu†, Meiling Wang†, Xiudong Liao, Liyang Zhang and Xugang Luo* \\ Mineral Nutrition Research Division, Institute of Animal Science, Chinese Academy of Agricultural Sciences (CAAS), \\ Beijing 100193, People's Republic of China
}

(Submitted 1 July 2017 - Final revision received 29 September 2017 - Accepted 5 October 2017)

\begin{abstract}
Two experiments were designed to investigate the effects of Mn source and concentration on the mRNA expression and enzymatic activities of fatty acid synthase (FAS) and malic enzyme (ME) in cultured primary broiler hepatocytes. In Expt 1, primary broiler hepatocytes were treated with 0 (control), $0.25,0.50$ or $0.75 \mathrm{mmol} / \mathrm{l}$ of $\mathrm{Mn}$ as inorganic manganese chloride $\left(\mathrm{MnCl}_{2} .4 \mathrm{H}_{2} \mathrm{O}\right)$ for 24 and $48 \mathrm{~h}$. In Expt 2 , primary broiler hepatocytes were incubated with 0 (control), 0.25 or $0.50 \mathrm{mmol} / \mathrm{l}$ of $\mathrm{Mn}$ as either manganese chloride or $\mathrm{Mn}$-amino acid chelate for $48 \mathrm{~h}$. The mRNA levels and activities of FAS and ME in the hepatocytes were measured in Expts 1 and 2 . The results in Expt 1 showed that only at $48 \mathrm{~h}$ mRNA expression levels of $F A S$ and $M E$ in the hepatocytes decreased linearly $(P<0.001)$ and quadratically $(P<0.02)$ as supplemental Mn concentrations increased. In Expt 2, compared with the control, Mn supplementation reduced $(P<0 \cdot 01)$ the activities of FAS, mRNA expression levels of $F A S$ and $M E$ in the hepatocytes, and the efflux of lactic dehydrogenase to the medium. The supplemental Mn at $0.5 \mathrm{mmol} / \mathrm{l}$ showed a lower $(P<0.03) M E$ mRNA expression level compared with the Mn group at $0.25 \mathrm{mmol} / \mathrm{l}$. However, Mn source and the interaction between $\mathrm{Mn}$ source and concentration had no impacts $(P>0.33)$ on any of the measured cellular parameters. The results suggested that Mn might reduce cell damage and regulate $F A S$ and $M E$ expression at a transcriptional level in primary cultured broiler hepatocytes.
\end{abstract}

Key words: Manganese: Gene expressions: Fatty acid synthase: Malic enzyme: Broiler hepatocytes

Excessive accumulation of lipids in the adipose tissue of modern broiler strains is a major concern for producers, because most of the fat depots are lost during evisceration of the carcass or processing of the meat, leading to lower meat yields. Studies in vitro and with intact chicks have demonstrated that liver is the major site of lipid biosynthesis in the chicken ${ }^{(1,2)}$. Most fatty acids are synthesised in the liver and transported via LDL for storage in adipose tissues as TAG in chickens and other avian species ${ }^{(3)}$. Fatty acid synthase (FAS) and malic enzyme (ME) are two enzymes necessary for de novo synthesis of long-chain fatty acids, and the activities of these enzymes are correlated with the rate of fatty acid synthesis in the livers of animals ${ }^{(4)}$. Hepatic FAS and ME activities and their mRNA expression levels were also correlated with the proportion of abdominal fat of broilers ${ }^{(5,6)}$. It was reported that the expression levels of hepatic FAS and ME mRNA correlated positively with the rate of synthesis of their respective enzyme proteins, indicating that the nutritional regulation of these enzyme levels is primarily at pre-translational steps ${ }^{(4,7,8)}$.

$\mathrm{Mn}$ is an essential trace element for animals. It is involved in the metabolism of carbohydrates, amino acids, protein and lipid as a constituent or activator of numerous enzymes ${ }^{(9)}$. The current National Research Council ${ }^{(10)}$ Mn requirement for broilers is $60 \mathrm{mg} / \mathrm{kg}$, but this requirement is primarily based upon studies conducted more than 60 to 70 years ago with birds of markedly different productive potentials from modern birds today and semi-purified diets ${ }^{(11-13)}$. Results from our previous study ${ }^{(14)}$ indicated that dietary $\mathrm{Mn}$ of $120 \mathrm{mg} / \mathrm{kg}$ was a satisfactory level for the growth performance, tissue Mn concentrations and Mn-containing superoxide dismutase (MnSOD) activity in heart of broilers fed a practical conventional diet from 1 to $28 \mathrm{~d}$ of age. More recent research findings indicate that the optimal Mn requirements for starter and grower broilers fed practical conventional diets are about 130 and $100 \mathrm{mg} / \mathrm{kg}$, respectively $^{(15,16)}$, which are much higher than the value $(60 \mathrm{mg} / \mathrm{kg})$ recommended by National Research Council ${ }^{(10)}$. It is reported that supplemental Mn in the diet of pigs reduced the amount of fat deposited in the carcass ${ }^{(17,18)}$. Some previous studies from our laboratory have demonstrated that dietary Mn supplementation $(100 \mathrm{mg} / \mathrm{kg})$ decreased abdominal fat deposition of broilers, and Mn amino acid with a moderate

Abbreviations: FAS, fatty acid synthase; LDH, lactic dehydrogenase; ME, malic enzyme; Mn-AA, Mn-amino acid chelate with moderate chelation strength; MnSOD, Mn-containing superoxide dismutase.

*Corresponding author: Professor X. Luo, fax +86 10 62810184, email wlysz@263.net

$\dagger$ These authors contributed equally to the present work. 
chelation strength (Mn-AA) was as effective as manganese sulfate $\left(\mathrm{MnSO}_{4} \cdot \mathrm{H}_{2} \mathrm{O}\right)^{(19,20)}$. These results suggest that feeding a normal level of Mn would decrease fat synthesis and body fat content. Our further study indicated that the addition of $100 \mathrm{mg} /$ $\mathrm{kg} \mathrm{Mn}$ as either $\mathrm{MnSO}_{4}$ or $\mathrm{Mn}-\mathrm{AA}$ to the diets decreased the activities of FAS and ME, and mRNA expression of $M E$ in the liver of broilers, and no differences were detected in these parameters between birds fed diets supplemented with $\mathrm{MnSO}_{4}$ and $\mathrm{Mn}-\mathrm{AA}^{(21)}$. However, the above results are all obtained from in vivo studies, and might have been affected by other factors, such as feed intake, other dietary factors, environmental factors and so on. Whether supplemental Mn could directly regulate FAS and ME activities and their gene expressions in primary chicken hepatocytes, as well as the underlying relationship between the regulation of the two enzymes and supplemental Mn sources, remain unknown.

The aim of the present study was to investigate the effects of Mn source and Mn level on FAS and ME activities and their mRNA expressions in in vitro-cultured primary chicken hepatocytes in order to explore whether Mn could directly regulate the activities and mRNA expressions of FAS and ME.

\section{Methods}

\section{Isolation and cultivation of primary chick hepatocytes}

All experimental procedures were approved by the Animal Management Committee (in charge of animal welfare issue) of the Institute of Animal Sciences, Chinese Academy of Agricultural Sciences (IAS-CAAS, Beijing, China), and performed in accordance with the guidelines. Ethical approval on animal survival was given by the animal ethics committee of IAS-CAAS. Hepatocytes were isolated from the liver tissue of 22-d-old male Arbor Acres broilers (Huadu Broiler Breeding Corp.) fed the Mn-deficient maize-soyabean meal diet (containing 19.69 mg $\mathrm{Mn} / \mathrm{kg}$ by analysis) during a period of 1 to $21 \mathrm{~d}$ of age to deplete the body $\mathrm{Mn}$ storage. In a previous study from our laboratory $^{(22)}$, when broilers were fed an Mn-deficient diet containing $23 \mathrm{mg} \mathrm{Mn} / \mathrm{kg}$ for $21 \mathrm{~d}$, they showed a moderate Mn deficiency as reflected by the increased incidence of leg abnormality, and decreased bone Mn, heart Mn and MnSOD activity. In the present study, the Mn-deficient diet contained a lower Mn level as mentioned above; therefore, the chickens should be in Mn deficiency. The hepatocytes isolated from birds fed an Mn-deficient diet could be Mn-deficient, and more sensitive to Mn supplementation. Hepatocyte isolation was performed by using the collagenase perfusion method as described previously ${ }^{(23)}$, with some modifications. Isolated cells were suspended in $40 \mathrm{ml}$ of L-15 medium (Invitrogen) supplemented with $10 \%$ fetal bovine serum (FBS), $10 \mu \mathrm{g} / \mathrm{ml}$ of transferrin, $10 \mu \mathrm{g} / \mathrm{ml}$ of vitamin $\mathrm{C}, 10^{-6} \mathrm{M}$ dexamethasone, $10^{-6} \mathrm{M}$ insulin and $1 \%$ antibiotics $(100 \mathrm{IU} / \mathrm{ml}$ of penicillin and $100 \mathrm{mg} / \mathrm{ml}$ of streptomycin) at $4^{\circ} \mathrm{C}$. Purification of hepatocytes was performed as described by Wu et al. ${ }^{(24)}$. The viability of the isolated hepatocytes was 95 (SD 1.3)\% ( $n$ 6), which was analysed by the $0.4 \%$ trypan blue dye exclusion method, and the cell yield from each liver preparation was $2 \cdot 0(\mathrm{SD} 1 \cdot 0) \times 10^{9}$ hepatocytes ( $n$ 6). Evaluation of the cells by using light microscopy showed that about $95 \%$ of the collected cells were hepatocytes.

The hepatocyte cultures were performed according to the method described by Fujii et al. ${ }^{(25)}$, with some modifications. Hepatocytes were seeded into six-well plates (Corning Life Sciences) at a density of $1.5 \times 10^{6}$ viable cells per well in $1.5 \mathrm{ml}$ of the above-mentioned L-15 medium. Cells were cultured at $37^{\circ} \mathrm{C}$ in a humidified incubator (Model 3110 series; Thermo Electron Corporation) with $5 \% \mathrm{CO}_{2}$ and $95 \%$ air. After a plating period of $6 \mathrm{~h}$, cell monolayers were washed twice with ice-cold PBS, and $3 \mathrm{ml}$ of fresh L-15 medium (supplemented with $10 \%$ FBS and $1 \%$ antibiotics (100 IU/ml of penicillin and $100 \mathrm{mg} / \mathrm{ml}$ of streptomycin)) was added to each well. After about $20 \mathrm{~h}$ of incubation in addition to the above plating period of $6 \mathrm{~h}$, these cells were used for the following experiments. In each experiment, hepatocytes were isolated individually from six replicate broilers per treatment and the cells from each replicate broiler were plated into six wells.

\section{A preliminary experiment to evaluate the viability of chick hepatocytes}

This experiment was conducted to measure the efflux of lactic dehydrogenase (LDH) from the hepatocytes treated with various amounts of $\mathrm{Mn}$ in order to find the optimal $\mathrm{Mn}$ supplementation range.

At the end of the above incubation, the culture medium of the cells was removed, and hepatocyte monolayers were washed three times with ice-cold PBS. Next, $3 \mathrm{ml}$ of serum-free L-15 medium (supplemented with $1 \%$ antibiotics $(100 \mathrm{IU} / \mathrm{ml}$ of penicillin and $100 \mathrm{mg} / \mathrm{ml}$ of streptomycin)) was added to each well, and the hepatocytes were treated with $0,0.02,0.20,0.50$ and $1.00 \mathrm{mmol} / \mathrm{l}$ of $\mathrm{Mn}$ as inorganic manganese chloride $\left(\mathrm{MnCl}_{2} \cdot 4 \mathrm{H}_{2} \mathrm{O}\right.$ ) (reagent grade; Beijing Biochemical Reagent Company) for 24- and 48-h incubation. After 24- or 48-h incubation, the culture medium was collected into 2-ml Eppendorf tubes, and then stored at $-20^{\circ} \mathrm{C}$. The activities of $\mathrm{LDH}$ were analysed according to the instructions in the commercial kits (Nanjing Jiancheng Bioengineering Institute). One unit of enzyme activity was defined as $1 \mathrm{mmol}$ of reduced nicotinamide adenine dinucleotide oxidised per min. The LDH activity in the culture medium was expressed as units per litre (U/l). All of the samples were measured in duplicate.

\section{Cell treatments}

Expt 1 was performed to investigate the effect of supplemental Mn concentration on the activities and mRNA expression of FAS and $\mathrm{ME}$ in the hepatocytes at a different incubation time. Our preliminary experiment indicated that cells treated with about $0.50 \mathrm{mmol} / \mathrm{l}$ of $\mathrm{Mn}$ as long as 24 or $48 \mathrm{~h}$ had the best viability. Therefore, in Expt 1, the hepatocytes were incubated in fresh serum-free L-15 medium, and treated with 0 (control), 0.25, 0.50 or $0.75 \mathrm{mmol} / \mathrm{l}$ of $\mathrm{Mn}$ as manganese chloride for 24 or $48 \mathrm{~h}$. The FAS and ME mRNA levels and enzymatic activities were determined after Mn treatments for 24 or $48 \mathrm{~h}$.

Expt 2 was performed to evaluate the effect of supplemental Mn source and concentration on the activities and mRNA expression of FAS and ME in the primary hepatocytes. The results in Expt 1 indicated that the Mn treatment affected $F A S$ and $M E$ 
mRNA expression only at $48 \mathrm{~h}$, and the dose of 0.25 or $0.50 \mathrm{mmol} / \mathrm{l}$ of Mn was effective in decreasing the mRNA expression of the two enzymes. Therefore, in Expt 2, the cells were incubated in the fresh serum-free L-15 medium, and treated with 0 (control), 0.25 or $0.50 \mathrm{mmol} / \mathrm{l}$ of $\mathrm{Mn}$ as manganese chloride or Mn-AA with a moderate chelation strength (quotient of formation $\left(Q_{\mathrm{f}}\right)=16 \cdot 85$ between 10 and 100, containing Mn 9.06\% and total amino acids 29.09\%; Sanbao Additive Company) for $48 \mathrm{~h}$. The $Q_{\mathrm{f}}$ is a quantitative measurement of chelation strength between $\mathrm{Mn}$ and amino acids according to the shift in half-wave potential $\left(E_{1 / 2}\right)$ in polarography, as described by Holwerda et al. ${ }^{(26)}$ and $\mathrm{Li}$ et $a l^{(22)}$. Lysine or Met concentration in each treatment was balanced by supplementation of additional L-lysine monohydrochloride or DL-methionine. The FAS and ME mRNA levels and enzymatic activities in hepatocytes, as well as the LDH activities in the medium, were determined after Mn treatments for $48 \mathrm{~h}$.

\section{Sample collections and preparations}

At the end of Expt 1, the medium was removed and the cell monolayer was washed three times with ice-cold PBS. The cells in the first two wells for each replicate were scraped in ice-cold $0 \cdot 1 \mathrm{~mol} / \mathrm{l}$ of potassium phosphate $(\mathrm{pH}=7 \cdot 0(\mathrm{sD} 0 \cdot 1)$ ), and then sonicated at $4^{\circ} \mathrm{C}$ for $4 \mathrm{~min}$ ( $1 \mathrm{~s}$ with 10 -s intervals). Lysates were centrifuged at $8000 \mathrm{~g}$ for $15 \mathrm{~min}$ at $4^{\circ} \mathrm{C}$ to harvest the supernatant to a new centrifuge tube, and then the supernatant was centrifuged at $20000 \boldsymbol{g}$ for $50 \mathrm{~min}$ at $4{ }^{\circ} \mathrm{C}$. The supernatant was collected for FAS activity analysis. The cells in the next two wells for each replicate were scraped in ice-cold saline, and then sonicated at $4^{\circ} \mathrm{C}$ for $4 \mathrm{~min}$ ( $1 \mathrm{~s}$ with 10 -s intervals). Lysates were centrifuged at $2000 \mathrm{~g}$ for $10 \mathrm{~min}$ at $4^{\circ} \mathrm{C}$ to harvest the supernatants for ME activity analysis. The cells in the other two wells for each replicate were scraped in TRIzol reagent (Life Technologies) and frozen $\left(-80^{\circ} \mathrm{C}\right)$ for $F A S$ and $M E$ mRNA expression analysis.

At the end of Expt 2, the culture medium in the first well for each replicate was collected and stored at $-20^{\circ} \mathrm{C}$ for the subsequent analysis of LDH activities. In addition, the cells in the second and third wells and the other three wells for each replicate were collected and prepared according to the procedures mentioned in Expt 1 for the subsequent analyses of FAS and ME activities and mRNA expression levels, respectively.

\section{Analysis of enzymatic activities}

The measurement of LDH activity in the incubation medium was performed as described in the above preliminary experiment. The protein concentrations in supernatants were determined by BCA protein assay kit (catalogue no. 233225; Thermo). The FAS activity was measured as described by Tian et $a l .{ }^{(27)}$. The ME activity was determined by the modified method of Hsu and Lardy ${ }^{(28)}$. The enzymatic activities were expressed as units (U) per $\mathrm{mg}$ of protein ( $\mathrm{U} / \mathrm{mg}$ prot.). One $U$ of FAS activity is noted as $\mu$ mol of oxidised NADPH per min per $\mathrm{mg}$ of protein at $37^{\circ} \mathrm{C}$. One $\mathrm{U}$ of $\mathrm{ME}$ activity is defined as $\mu \mathrm{mol}$ of reduced NADP per min per mg of protein at $30^{\circ} \mathrm{C}$. All of the samples were measured in duplicate.

\section{Determinations of fatty acid synthase and malic enzyme mRNA expression levels}

The concentrations of total RNA were estimated by measuring ultraviolet light absorbance at $260 \mathrm{~nm}$ with a spectrophotometer (NanoDrop 2000; Gene Company Ltd). In brief, complementary DNA was synthesised using the SuperScript_III First-Strand Synthesis for RT-PCR kit (Invitrogen) with DNA Engine PCR instrument (Bio-Rad). The FAS and $M E$ mRNA expression levels were determined by relative quantitative realtime PCR using the power SYBR ${ }^{\circledR}$ Green PCR mater mix kit (catalogue no. 4367659; Applied Biosystems) with ABI Prism 7500 (Applied Biosystems) as described by Li et al. ${ }^{(29)}$. The information of primers was listed in Table 1 . The $\beta$-actin was used as the internal reference to normalise the FAS and $M E$ mRNA expression levels using the $2^{-\Delta \Delta C_{t}} \operatorname{method}^{(30,31)}$. All of the samples were measured in duplicate.

\section{Statistical analyses}

The data in the preliminary experiment and Expt 1 were analysed by one-way ANOVA using the general linear model (GLM) procedure of the SAS 9.2 (SAS Institute Inc.). Orthogonal polynomials were used to assess linear and quadratic responses to added Mn levels. In addition, regression analysis was used to fit the data in the preliminary experiment to determine the optimal added Mn concentration in the medium. Data in Expt 2 were analysed using single degree of freedom contrast to compare all supplemental Mn treatments with the control ${ }^{(32,33)}$. Data excluding the control were analysed by two-way ANOVA using the GLM procedure (SAS Institute Inc.). The model included the effects of Mn source, supplemental Mn concentration and their interaction. The replicate served as the experimental unit. If the variances were significant, differences among means were tested by the LSD method, and the statistical significance was set at $P \leq 0.05$.

Table 1. Primer sequences for real-time PCR amplification

\begin{tabular}{lllc}
\hline Genes & GenBank identity & Primer sequence (5'-3') & Product length (bp) \\
\hline FAS & J03860 & F: AGCGTGCTATGCTTGCC & 129 \\
ME & AF408407 & R: GTCCGTGACGAATTGCTTTAT & 236 \\
$\beta$-Actin & R: GATTACGGTTTAGCATTTCGG & 152 \\
& L08165 & F: GAGAAATTGTGCGTGACATCA & \\
\hline
\end{tabular}

FAS, fatty acid synthase; $M E$, malic enzyme; $F$, forward; $\mathrm{R}$, reverse. 


\section{Results}

Effect of supplemental manganese concentration on the lactic dehydrogenase release (preliminary experiment)

The addition of Mn significantly affected $(P<0 \cdot 0001) \mathrm{LDH}$ activities (Table 2 ) in the medium after incubation for 24 and $48 \mathrm{~h}$. The LDH activities decreased linearly $(P<0.003)$ and quadratically $(P<0.0001)$ as $\mathrm{Mn}$ concentrations increased at either 24 or $48 \mathrm{~h}$, and the lowest LDH activity was at a supplemental Mn concentration of $0.50 \mathrm{mmol} / \mathrm{l}$. On the basis of the fitted quadratic models of $\mathrm{LDH}$ activities with added Mn concentrations (24h: $Y=610 \cdot 5-1271 \cdot 6 X+1110 \cdot 3 X^{2}, \quad R^{2}=0 \cdot 8194$, $P<0.0001 ; 48 \mathrm{~h}: \quad Y=1268 \cdot 7-1623 \cdot 1 X+1441 \cdot 7 X^{2}, R^{2}=0.6475$, $P<0.0001$ ), the optimal added Mn concentrations were $0.57 \mathrm{mmol} / \mathrm{l}$ at $24 \mathrm{~h}$ and $0.56 \mathrm{mmol} / \mathrm{l}$ at $48 \mathrm{~h}$, respectively.

Table 2. Effect of supplemental manganese concentration on the activities of lactic dehydrogenase (LDH) in the culture medium of chicken hepatocytes at a different incubation time (preliminary experiment)

\begin{tabular}{|c|c|c|}
\hline \multirow[b]{2}{*}{ Supplemental $\mathrm{Mn}(\mathrm{mmol} / \mathrm{l})$} & \multicolumn{2}{|c|}{ LDH activities $(\mathrm{U} / \mathrm{l})^{*}$} \\
\hline & $24 \mathrm{~h}$ & $48 \mathrm{~h}$ \\
\hline $0 †$ & $689^{a}$ & $1202^{a, b}$ \\
\hline $0.02 \dagger$ & $510^{b}$ & $1273^{a}$ \\
\hline $0.20 \dagger$ & $384^{c}$ & $1069^{C}$ \\
\hline $0.50 \dagger$ & $268^{d}$ & $772^{\mathrm{d}}$ \\
\hline $1.00 \dagger$ & $445^{\mathrm{b}, \mathrm{c}}$ & $1096^{\mathrm{b}, \mathrm{c}}$ \\
\hline Pooled SEM & 29 & 49 \\
\hline \multicolumn{3}{|l|}{$P$} \\
\hline Mn concentration & $<0.0001$ & $<0.0001$ \\
\hline Mn linear & $<0.0001$ & 0.0023 \\
\hline Mn quadratic & $<0.0001$ & $<0.0001$ \\
\hline
\end{tabular}

Effect of supplemental manganese concentration on the activities and mRNA expression levels of fatty acid synthase and malic enzyme (Expt 1)

Mn supplementation did not influence $(P>0 \cdot 17)$ the FAS and ME activities in chicken hepatocytes at 24 and $48 \mathrm{~h}$, and their mRNA expression levels at $24 \mathrm{~h}$, but did affect $(P<0.001)$ their mRNA expression levels at $48 \mathrm{~h}$ (Table 3). As supplemental Mn concentrations increased, linear $(P<0.0007)$ and quadratic $(P<0.02)$ responses were observed in $F A S$ and $M E$ mRNA expression.

\section{Effects of supplemental manganese source and concentration on the lactic dehydrogenase release (Expt 2)}

Compared with the control, the addition of either 0.25 or $0.50 \mathrm{mmol} / \mathrm{l}$ of $\mathrm{Mn}$ as either manganese chloride or $\mathrm{Mn}-\mathrm{AA}$ significantly decreased $(P<0 \cdot 01) \mathrm{LDH}$ activities in the culture medium (Table 4). However, Mn source, Mn concentration and their interaction did not affect $(P>0 \cdot 13) \mathrm{LDH}$ activities in the culture medium.

\section{Effects of supplemental manganese source and concentration on the activities and mRNA expression levels of fatty acid synthase and malic enzyme (Expt 2)}

Compared with the control, supplemental $\mathrm{Mn}$ as either $\mathrm{Mn}$ chloride or $\mathrm{Mn}-\mathrm{AA}$ at either 0.25 or $0.50 \mathrm{mmol} / \mathrm{l}$ significantly decreased $(P<0.004)$ FAS activities and the mRNA expression levels of $F A S$ and $M E$ in chicken hepatocytes, but had no effect $(P>0.76)$ on the ME activities (Table 5$)$. The Mn source, Mn concentration and their interaction did not affect $(P>0 \cdot 19)$ FAS and ME activities, and FAS mRNA expression levels. The Mn source or an interaction between Mn source and Mn concentration had no effect $(P>0 \cdot 22)$ on the $M E$ mRNA expression

Table 3. Effect of supplemental manganese concentration on the activities and mRNA expression levels of fatty acid synthase (FAS) and malic enzyme (ME) in chicken hepatocytes at a different incubation time (Expt 1)

\begin{tabular}{|c|c|c|c|c|c|c|c|c|}
\hline \multirow[b]{3}{*}{$\begin{array}{l}\text { Supplemental Mn } \\
(\mathrm{mmol} / \mathrm{l})\end{array}$} & \multicolumn{4}{|c|}{$24 \mathrm{~h}$} & \multicolumn{4}{|c|}{$48 \mathrm{~h}$} \\
\hline & \multicolumn{2}{|c|}{ FAS } & \multicolumn{2}{|l|}{$\mathrm{ME}$} & \multicolumn{2}{|l|}{ FAS } & \multicolumn{2}{|l|}{$\mathrm{ME}$} \\
\hline & $\begin{array}{c}\text { Activity } \\
(\mathrm{U} / \mathrm{mg} \text { prot. })^{*}\end{array}$ & $\begin{array}{c}\text { mRNA } \\
\text { (RQ)† }\end{array}$ & $\begin{array}{c}\text { Activity } \\
(\mathrm{U} / \mathrm{mg} \text { prot. })^{\star}\end{array}$ & $\begin{array}{c}\text { mRNA } \\
\text { (RQ)† }\end{array}$ & $\begin{array}{c}\text { Activity } \\
(\mathrm{U} / \mathrm{mg} \text { prot. })^{\star}\end{array}$ & $\begin{array}{c}\text { mRNA } \\
(\mathrm{RQ}) \dagger\end{array}$ & $\begin{array}{c}\text { Activity } \\
(\mathrm{U} / \mathrm{mg} \text { prot. })^{*}\end{array}$ & $\begin{array}{c}\text { mRNA } \\
(\mathrm{RQ}) \dagger\end{array}$ \\
\hline $0 \ddagger$ & 3.07 & 3.53 & 6.02 & $1 \cdot 18$ & 3.45 & $3.90^{a}$ & 5.54 & $1 \cdot 74^{a}$ \\
\hline $0.25 \ddagger$ & 3.02 & $2 \cdot 82$ & 5.53 & 0.69 & 2.69 & $1 \cdot 31^{b}$ & $4 \cdot 12$ & $0.47^{b}$ \\
\hline $0.50 \ddagger$ & 2.89 & 1.97 & 5.83 & 0.58 & $2 \cdot 22$ & $0.39^{b}$ & 5.00 & $0.36^{b}$ \\
\hline $0.75 \ddagger$ & $2 \cdot 79$ & 2.65 & $5 \cdot 78$ & 0.58 & $2 \cdot 38$ & $0.46^{\mathrm{b}}$ & $4 \cdot 33$ & $0.45^{\mathrm{b}}$ \\
\hline $\begin{array}{l}\text { Pooled SEM } \\
P\end{array}$ & 0.19 & 0.63 & 0.39 & 0.23 & 0.46 & 0.46 & 0.46 & 0.24 \\
\hline $\begin{array}{l}\text { Mn concentration } \\
\text { Mn linear } \\
\text { Mn quadratic }\end{array}$ & 0.72 & 0.48 & 0.87 & 0.24 & 0.19 & $\begin{array}{l}0.0001 \\
0.0001 \\
0.009\end{array}$ & 0.17 & $\begin{array}{l}0.0009 \\
0.0006 \\
0.015\end{array}$ \\
\hline
\end{tabular}

FAS, fatty acid synthase; $M E$, malic enzyme; $U$, unit; $R Q$, relative quantities.

${ }^{\mathrm{a}, \mathrm{b}}$ Mean values within a column with unlike superscript letters were significantly different $(P<0.01)$.

* One $U$ of FAS activity is noted as $\mu$ mol of oxidised NADPH per min per mg of protein at $37^{\circ} \mathrm{C}$; one $\mathrm{U}$ of ME activity is defined as $\mu$ mol of reduced NADP per min per $\mathrm{mg}$ of protein at $30^{\circ} \mathrm{C}$.

$\dagger$ The FAS or ME mRNA abundances were calculated as the RQ of the $F A S$ or $M E m R N A$ to the internal reference gene $\beta$-actin $m R N A ; R Q=2^{-\triangle \Delta C_{t}}$ $\left(C_{t}=\right.$ threshold cycle).

‡ Data represent the means of six replicates $(n 6)$. 
levels. However, the $M E$ mRNA levels were influenced $(P<0.03)$ by Mn concentration, and were lower $(P<0.03)$ at $0.50 \mathrm{mmol} / \mathrm{l}$ than at $0.25 \mathrm{mmol} / \mathrm{l}$.

Table 4. Effects of supplemental manganese source and concentration on the activity of lactic dehydrogenase (LDH) in the culture medium of chicken hepatocytes (Expt 2)

\begin{tabular}{lcc}
\hline Mn source & Mn concentration $(\mathrm{mmol} / \mathrm{l})$ & LDH activity $(\mathrm{U} / \mathrm{l})^{*}$ \\
\hline Control & $0 \dagger$ & $1853 \ddagger$ \\
Manganese chloride & $0.25 \dagger$ & 1775 \\
& $0.50 \dagger$ & 1540 \\
Mn-AA & $0.25 \dagger$ & 1591 \\
Pooled SEM & $0.50 \dagger$ & 1556 \\
Mn source & & 77 \\
& Manganese chloride§ & 1657 \\
Pooled SEM & Mn-AA§ & 1574 \\
Mn concentration & & 62 \\
& & \\
Pooled SEM & $0.25 \S$ & 1683 \\
$P$ Mn source & $0.50 \S$ & 1548 \\
Mn concentration & & 56 \\
Interaction & & 0.33 \\
\hline
\end{tabular}

Manganese chloride, $\mathrm{MnCl}_{2} \cdot 4 \mathrm{H}_{2} \mathrm{O} ; \mathrm{Mn}-\mathrm{AA}, \mathrm{Mn}$-amino acid chelate with a moderate chelation strength $\left(Q_{\mathrm{f}}=16 \cdot 85\right)$.

* One unit of LDH activity was defined as $1 \mathrm{mmol}$ of reduced nicotinamide adenine dinucleotide oxidised per min.

$\dagger$ Data represent the means of six replicates $(n 6)$.

‡ Different $(P<0.01)$ from all Mn supplemental groups.

$\S$ Data represent the means of twelve replicates $(n 12)$.

\section{Discussion}

LDH is a stable cytosolic enzyme, which becomes extracellular when the cell membrane is damaged. The activity of LDH in the culture medium is an indicator of cellular integrity and vitality, and are commonly used to evaluate the cytotoxicity ${ }^{(34,35)}$. The effect of $\mathrm{Mn}$ on the viabilities of primary cultured chicken hepatocytes has not been reported. The results from the present study showed that the addition of $\mathrm{Mn}$ as either manganese chloride or Mn-AA decreased the leakage of LDH from hepatocytes, and thereby improved the integrity and vitality of hepatocytes. On the basis of the data of $\mathrm{LDH}$ activities from the preliminary experiment and Expt 2, the appropriate supplemental Mn concentration was about $0.50 \mathrm{mg} / \mathrm{kg}$. Similar results were observed in an experiment ${ }^{(36)}$ with primary broiler myocardial cells, suggesting that $\mathrm{Mn}$ supplementation with $0.50 \mathrm{mmol} / 1$ could have the best cell viability.

FAS, a key enzyme in lipogenesis of animals, is involved in the conversion of acetyl CoA and malonyl CoA to palmitate. The content of FAS in liver changes drastically when animals are subjected to different nutritional states. Refeeding starved rats and chickens caused a substantial increase in the rate of FAS synthesis in liver ${ }^{(4,37)}$. It is confirmed that the nutritional regulation of the FAS synthesis was primarily due to regulation of the amount of $F A S$ mRNA in liver of chicks ${ }^{(4,7,8)}$. However, the information is still limited regarding the effect of Mn on the activity and gene expression of FAS in the liver of animals. In the present study, the FAS activity was not altered in Expt 1, but decreased in Expt 2. The disparity in these results might be majorly because of the greater variations within the groups in

Table 5. Effects of supplemental manganese source and concentration on the activities and mRNA expression levels of fatty acid synthase (FAS) and malic enzyme (ME) in chicken hepatocytes (Expt 2)

\begin{tabular}{|c|c|c|c|c|c|}
\hline Mn source & $\begin{array}{l}\text { Mn concentration } \\
(\mathrm{mm})\end{array}$ & $\begin{array}{l}\text { FAS activity } \\
\text { (U/mg prot.. })^{*}\end{array}$ & $\begin{array}{c}\text { FAS mRNA } \\
(\mathrm{RQ}) \dagger\end{array}$ & $\begin{array}{l}\text { ME activity } \\
\text { (U/mg prot. })^{*}\end{array}$ & $\begin{array}{c}\text { ME mRNA } \\
(\mathrm{RQ}) \dagger\end{array}$ \\
\hline Control & $0 \ddagger$ & $3.91 \S$ & $1.81 \S$ & 11.51 & $2 \cdot 14 \S$ \\
\hline \multirow[t]{2}{*}{ Manganese chloride } & $0.25 \ddagger$ & 2.86 & 0.59 & 11.08 & 0.77 \\
\hline & $0.50 \ddagger$ & 3.04 & 0.55 & $11 \cdot 17$ & 0.66 \\
\hline \multirow{2}{*}{$\mathrm{Mn}-\mathrm{AA}$} & $0.25 \ddagger$ & $3 \cdot 15$ & 0.92 & 11.02 & 0.83 \\
\hline & $0.50 \ddagger$ & 2.94 & 0.42 & 9.90 & 0.48 \\
\hline \multirow{3}{*}{$\begin{array}{l}\text { Pooled SEM } \\
\text { Mn source }\end{array}$} & & 0.27 & 0.20 & 0.94 & 0.10 \\
\hline & Manganese chloride & 2.95 & 0.57 & $11 \cdot 12$ & 0.71 \\
\hline & Mn-AAT & 3.04 & 0.67 & 10.44 & 0.66 \\
\hline \multirow{3}{*}{$\begin{array}{l}\text { Pooled SEM } \\
\text { Mn concentration }\end{array}$} & & 0.19 & 0.15 & 0.71 & 0.07 \\
\hline & $0.25 \pi$ & 3.00 & 0.75 & 11.05 & $0.80^{\mathrm{a}}$ \\
\hline & 0.509 & 2.98 & 0.48 & 10.51 & $0.57^{\mathrm{b}}$ \\
\hline \multicolumn{6}{|l|}{$P$} \\
\hline Mn source & & 0.72 & 0.64 & 0.50 & 0.58 \\
\hline Mn concentration & & 0.96 & 0.19 & 0.59 & 0.028 \\
\hline Interaction & & 0.48 & 0.27 & 0.53 & 0.23 \\
\hline
\end{tabular}

FAS, fatty acid synthase; $\mathrm{RQ}$, relative quantities; $\mathrm{ME}$, malic enzyme; $\mathrm{U}$, unit; manganese chloride, $\mathrm{MnCl}_{2} \cdot 4 \mathrm{H}_{2} \mathrm{O} ; \mathrm{Mn}-\mathrm{AA}, \mathrm{Mn}^{-a m i n o}$ acid chelate with a moderate chelation strength $\left(Q_{\mathrm{f}}=16.85\right)$

a,b Mean values within a column with unlike superscript letters were significantly different $(P<0.03)$.

* One $U$ of FAS activity is noted as $\mu$ mol of oxidised NADPH per min per mg of protein at $37^{\circ} \mathrm{C}$. One $U$ of ME activity is defined as $\mu$ mol of reduced NADP per min per $\mathrm{mg}$ of protein at $30^{\circ} \mathrm{C}$.

† The FAS or ME mRNA abundances were calculated as the RQ of the $F A S$ or $M E$ mRNA to the internal reference gene $\beta$-actin $m R N A$; $R Q=2^{-\triangle \Delta C_{t}}$ $\left(C_{t}=\right.$ threshold cycle).

$\ddagger$ Data represent the means of six replicates $(n 6)$.

$\S$ Different $(P<0.004)$ from all Mn supplemental groups.

II Data represent the means of twelve replicates $(n 12)$. 
Expt 1 than in Expt 2, which led to the non-significant results in Expt 1. Wang et al. ${ }^{(21)}$ demonstrated that the inclusion of $100 \mathrm{mg} / \mathrm{kg}$ of $\mathrm{Mn}$ as either $\mathrm{MnSO}_{4}$ or $\mathrm{Mn}-\mathrm{AA}$ in the diets reduced FAS activity, but did not affect its mRNA expression in the liver of broilers. However, the results from the current study showed that the addition of Mn as either manganese chloride or Mn-AA decreased both the activity and mRNA expression of FAS in the chicken hepatocytes. The disparities in the results of FAS mRNA among the two studies might be due to the differences in experimental type (present in vitro $v$. previous in vivo ${ }^{(14)}$ studies), supplemental Mn levels and so on. The results from the present study also suggest that the regulation of hepatic FAS activity by Mn might be at a pre-translational level.

Our previous studies have demonstrated that when Mn sources were supplied through either diets, or i.v. injections, the organic Mn with a moderate chelation strength was more effective than $\mathrm{MnSO}_{4}$ or organic Mn sources with weak or strong chelation strength in activating $M n S O D$ gene expression in the heart of broilers at both mRNA and protein levels ${ }^{(22,38-41)}$. This might result from greater intestinal absorption and/or tissue utilisation of the organic Mn source with moderate chelation strength in broilers ${ }^{(41-43)}$. A further in vitro study from our laboratory also indicated that Mn-AA was more effective than manganese chloride in enhancing $M n S O D$ mRNA expression in the primary broiler myocardial cells ${ }^{(29)}$. However, Wang et $a l .{ }^{(21)}$ found that both $\mathrm{Mn}-\mathrm{AA}$ and $\mathrm{MnSO}_{4}$ exhibited similar efficacies in regard to enhancing the FAS activity in the liver of broilers. Similarly, in the present study, no differences were detected in FAS activity and its mRNA expression of broiler hepatocytes between Mn-AA and manganese chloride. Differences in parameters chosen in different studies (heart MnSOD mRNA ${ }^{(22,38-40)}$ or protein expression ${ }^{(41)} v$. liver FAS activity $^{(21)}$; MnSOD mRNA expression in myocardial cells ${ }^{(29)} v$. present FAS activity and its mRNA expression in hepatocytes) may offer explanations to why the efficacies of Mn-AA M differed among the experiments.

ME is one of the key lipogenic enzymes in mammals and chickens. This enzyme carries out the irreversible decarboxylation of malate to pyruvate with the formation of NADPH from $\mathrm{NADP}^{+}$, and then this NADPH is vital for fatty acid biosynthesis $^{(44,45)}$. Nutritional regulation of the $M E$ gene in animals has been investigated. Switching rats from a regular chow diet to a fat-free high-carbohydrate diet induced hepatic ME activity and its mRNA level ${ }^{(46)}$. In poultry, liver is the primary site of ME expression $^{(47)}$. It is reported that hepatic ME activity and the abundance of its mRNA in chickens were tightly controlled by nutritional conditions ${ }^{(46)}$, and nutritional regulation of the synthesis of the enzyme is primarily at a pre-translational level $^{(4)}$. A previous study ${ }^{(21)}$ from our laboratory demonstrated that dietary $\mathrm{Mn}$ supplementation with $100 \mathrm{mg} / \mathrm{kg}$ as either $\mathrm{Mn}-\mathrm{AA}$ or $\mathrm{MnSO}_{4}$ decreased hepatic ME activity and its mRNA expression in broilers, indicating that $\mathrm{Mn}$ could regulate the chicken $M E$ gene expression at a transcriptional level. In the current study, the $M E$ mRNA was not significantly decreased at $24 \mathrm{~h}$ but only at $48 \mathrm{~h}$, indicating that Mn could decrease $M E$ mRNA expression in the primary broiler hepatocytes in a timedependent manner. In addition, our present study showed that the addition of either 0.25 or $0.50 \mathrm{mmol} / \mathrm{l}$ of $\mathrm{Mn}$ as either $\mathrm{Mn}-\mathrm{AA}$ or manganese chloride inhibited the $M E \mathrm{mRNA}$ expression, but had no effect on the ME activity in chicken hepatocytes, suggesting that this enzyme expression might be also modulated by $\mathrm{Mn}$ at both transcriptional and posttranscriptional levels. The discrepancy in results of ME activity between the present study and our previous study ${ }^{(21)}$ might be partially due to the differences in Mn levels and experimental types (present in vitro $v$. previous in vivo ${ }^{(21)}$ studies) used in the two studies. Further studies are needed to address how Mn affects gene expressions of $F A S$ and $M E$ in the future.

Until now, the influence of Mn source on ME activity and expression has only been reported by researchers from our laboratory. An earlier study ${ }^{(20)}$ from our laboratory demonstrated that the addition of either 100 or $200 \mathrm{mg} / \mathrm{kg} \mathrm{Mn}$ as $\mathrm{Mn}-\mathrm{AA}$ or $\mathrm{MnSO}_{4}$ decreased ME activities in abdominal fat of broilers, but no differences were detected between Mn-AA and $\mathrm{MnSO}_{4}$ treatments. Subsequently, we observed that Mn-AA and $\mathrm{MnSO}_{4}$ had similar efficacies in regulating the hepatic ME mRNA and activity of broilers ${ }^{(21)}$. The results from the current study are consistent with the above results, indicating that $\mathrm{Mn}-\mathrm{AA}$ was as effective as manganese chloride in reducing $M E$ mRNA expression in primary cultured chicken hepatocytes. These results also implied that hepatic ME activity and its mRNA expression were also not sensitive indicators in distinguishing the effectiveness of Mn sources.

In conclusion, the results from the present study indicate that Mn supplementation as either Mn-AA or manganese chloride decreased the activity of FAS and the mRNA expression of FAS and $M E$ in cultured primary chicken hepatocytes. Mn supplementation also reduced the hepatocyte damage. Compared with manganese chloride, Mn-AA had a similar effect on the measured cellular parameters. These results suggest that Mn might directly modulate the $F A S$ and $M E$ expressions at a transcriptional level. These findings might provide a further insight into the specific regulatory mechanism of the two enzymes by $\mathrm{Mn}$.

\section{Acknowledgements}

The authors are grateful to the staff in this laboratory for their valuable input to this study.

The present study was supported by the Agricultural Science and Technology Innovation Program (ASTIPIAS08), the China Agriculture Research System (grant no. CARS-41) and the National Natural Science Foundation of China (grant no. 30771575).

The authors' contributions are as follows: X. L. and L. L. designed the experiment; L. L. drafted the manuscript; X. L. and $\mathrm{X}$. L. participated in writing and editing of the manuscript; M. W. conducted most of the experiments and analysed the data; L. Z. performed the analysis of some parameters; and X. L. had primary responsibility for the final content. All authors read and approved the final version of the manuscript.

The authors declare that there are no conflicts of interest.

\section{References}

1. Leveille GA, Romsos DR, Yeh YY, et al. (1975) Lipid biosynthesis in the chick. A consideration of site of synthesis, influence of diet and possible regulatory mechanisms. Poult Sci 54, 1075-1093. 
2. Saadoun A \& Leclercq B (1987) In vivo lipogenesis of genetically lean and fat chickens: effects of nutritional state and dietary fat. $J$ Nutr 117, 428-435.

3. Hermier D (1997) Lipoprotein metabolism and fattening in poultry. J Nutr 127, $805 \mathrm{~S}$

4. Morris SM Jr, Winberry LK, Fisch JE, et al. (1984) Developmental and nutritional regulation of the messenger RNAs for fatty acid synthase, malic enzyme and albumin in the livers of embryonic and newly-hatched chicks. Mol Cell Biochem 64, 63-68.

5. Whitehead CC, Hood RL, Heard GS, et al. (1984) Comparison of plasma very low density lipoproteins and lipogenic enzymes as predictors of fat content and food conversion efficiency in selected lines of broiler chickens. Br Poult Sci $\mathbf{2 5}$, 277-286.

6. Yang Y (2005) Studies on the metabolism of intramuscular fat in quality chicken and its relationships with meat quality traits. Doctoral dissertation, Graduate School of Chinese Academy of Agricultural Sciences.

7. Morris SMJ, Nilson JH, Jenik RA, et al. (1982) Molecular cloning of gene sequences for avian fatty acid synthase and evidence for nutritional regulation of fatty acid synthase mRNA concentration. J Biol Chem 257, 3225-3229.

8. Goodridge AG, Jenik RA, Mcdevitt MA, et al. (1984) Malic enzyme and fatty acid synthase in the uropygial gland and liver of embryonic and neonatal ducklings. Tissue-specific regulation of gene expression. Arch Biochem Biophys 230, 82-92.

9. Erikson KM, Syversen T, Aschner JL, et al. (2005) Interactions between excessive manganese exposures and dietary irondeficiency in neurodegeneration. Environ Toxicol Pharmacol 19, 415-421.

10. National Research Council (1994) Nutrient Requirements of Poultry, 9th ed. Washington, DC: National Academies Press.

11. Wilgus HS, Norris LC \& Heuser GF (1937) The role of manganese and certain other trace elements in the prevention of perosis. J Nutr 14, 155-167.

12. Insko WM, Lyons $\mathrm{M} \&$ Martin JH (1938) The quantitative requirement of the growing chick for manganese. J Nutr $\mathbf{1 5}$, 621-627.

13. Gallup WD \& Norris LC (1939) The amount of manganese required to prevent perosis in the chick. Poult Sci 18, 76-82.

14. Luo XG, Su Q, Huang JC \& Liu JX (1991) A study on the optimal manganese (Mn) level in a practical diet of broiler chicks. Chin J Anim Vet Sci 22, 313-317.

15. Li S, Lin Y, Lu L, et al. (2011) An estimation of the manganese requirement for broilers from 1 to 21 days of age. Biol Trace Elem Res 143, 939-948.

16. Lu L, Chang B, Liao X, et al. (2016) Use of molecular biomarkers to estimate manganese requirements for broiler chickens from 22 to $42 \mathrm{~d}$ of age. Br J Nutr 116, 1512-1518.

17. Plumlee MP, Thrasher DM, Beeson WM, et al. (1956) The effects of a manganese deficiency upon the growth, development, and reproduction of swine. J Anim Sci 15, 352-367.

18. Atherton D (1993) A nutritional approach to carcass leanness. In The Role of Amino Acid Chelates in Animal Nutrition, pp. 269-287 [HD Ashmead, editor]. Park Ridge, NJ: Noyes Publication

19. Lu L, Ji C, Luo XG, et al. (2006) The effect of supplemental manganese in broiler diets on abdominal fat deposition and meat quality. Anim Feed Sci Tech 129, 49-59.

20. Lu L, Luo XG, Ji C, et al. (2007) Effect of manganese supplementation and source on carcass traits, meat quality, and lipid oxidation in broilers. J Anim Sci $\mathbf{8 5}, 812-822$.

21. Wang M, Chen Z, Lu L, et al. (2011) Effect of different manganese sources on activities and gene expression of key enzymes in fat metabolism of broilers. Sci Agri Sin $\mathbf{4 4}$, 3850-3858

22. Li S, Luo X, Liu B, et al. (2004) Use of chemical characteristics to predict the relative bioavailability of supplemental organic manganese sources for broilers. J Anim Sci 82, 2352-2363.

23. Fraslin J, Touquette L, Douaire M, et al. (1992) Isolation and long-term maintenance of differentiated adult chicken hepatocytes in primary culture. In Vitro Cell Dev Biol 28, 615-620.

24. Wu X, Huang K, Wei C, et al. (2010) Regulation of cellular glutathione peroxidase by different forms and concentrations of selenium in primary cultured bovine hepatocytes. $J$ Nutr Biochem 21, 153-161.

25. Fujii M, Yoshino I, Suzuki M, et al. (1996) Primary culture of chicken hepatocytes in serum-free medium ( $\mathrm{pH} 7 \cdot 8$ ) secreted albumin and transferrin for a long period in free gas exchange with atmosphere. Int J Biochem Cell Biol 28, 1381.

26. Holwerda RA, Albin RC \& Madsen FC (1995) Chelation effectiveness of zinc proteinates demonstrated. Feedstuffs $\mathbf{6 7}$, $12-13,23$.

27. Tian WX, Hsu RY \& Wang YS (1985) Studies on the reactivity of the essential sulfhydryl groups as a conformational probe for the fatty acid synthetase of chicken liver. Inactivation by 5,5'-dithiobis-(2-nitrobenzoic acid) and intersubunit cross-linking of the inactivated enzyme. J Biol Chem 260, 11375-11387.

28. Hsu RY \& Lardy HA (1969) Malic enzyme. Methods Enzymol 13, 230-235

29. Li S, Lin L, Liao X, et al. (2016) Manganese elevates manganese superoxide dismutase protein level through protein kinase C and protein tyrosine kinase. Biometals 29, 265-274.

30. Livak KJ \& Schmittgen TD (2001) Analysis of relative gene expression data using real-time quantitative PCR and the 2(-Delta Delta C(T)) method. Methods 25, 402-408.

31. Zhu YW, Lu L, Li WX, et al. (2015) Effects of maternal dietary manganese and incubation temperature on hatchability, antioxidant status, and expression of heat shock proteins in chick embryos. J Anim Sci $\mathbf{9 3}, 5725-5734$.

32. Suo H, Lu L, Zhang L, et al. (2015) Relative bioavailability of zinc-methionine chelate for broilers fed a conventional cornsoybean meal diet. Biol Trace Elem Res 146, 181-186.

33. Zhang LY, Lu L \& Luo XG (2016) The chemical characteristics of organic iron sources and their relative bioavailabilities for broilers fed a conventional corn-soybean meal diet. J Anim Sci 94, 2378-2396.

34. Mitchell DB \& Acosta D (1981) Evaluation of the cytotoxicity of tricyclic antidepressants in primary cultures of rat hepatocytes. J Toxicol Environ Health 7, 83-92.

35. Mcqueen CA \& Williams GM (1982) Cytotoxicity of xenobiotics in adult rat hepatocytes in primary culture. Fundam Appl Toxicol 2, 139.

36. Gao $\mathrm{T}$, Wang $\mathrm{F}$, Li S, et al. (2011) Manganese regulates manganese-containing superoxide dismutase (MnSOD) expression in the primary broiler myocardial cells. Biol Trace Elem Res 144, 695-704.

37. Lakshmanan MR, Nepokroeff CM \& Porter JW (1972) Control of the synthesis of fatty-acid synthetase in rat liver by insulin, glucagon, and adenosine $3^{\prime}: 5^{\prime}$ cyclic monophosphate. Proc Natl Acad Sci U S A 69, 3516-3519.

38. Li SF, Luo XG, Lu L, et al. (2005) Bioavailability of organic manganese sources in broilers fed high dietary calcium. Anim Feed Sci Tech 123-124, 703-715.

39. Luo XG, Li SF, Lu L, et al. (2007) Gene expression of manganese-containing superoxide Dismutase as a biomarker of manganese bioavailability for manganese sources in broilers. Poult Sci 86, 888-894. 
40. Li SF, Luo XG, Lu L, et al. (2008) Effect of intravenously injected manganese on the gene expression of manganese-containing superoxide dismutase in broilers. Poult Sci 87, 2259-2265.

41. Li S, Lu L, Hao S, et al. (2011) Dietary manganese modulates expression of the manganese-containing superoxide dismutase gene in chickens. $J$ Nutr 141, 189-194.

42. Ji F, Luo XG, Lu L, et al. (2006) Effects of manganese source and calcium on manganese uptake by in vitro everted gut sacs of broilers' intestinal segments. Poult Sci 85, 1217-1225.

43. Ji F, Luo XG, Lu L, et al. (2006) Effect of manganese source on manganese absorption by the intestine of broilers. Poult Sci 85, 1947-1952.

44. Yoshimoto K, Nakamura T \& Ichihara A (1983) Reciprocal effects of epidermal growth factor on key lipogenic enzymes in primary cultures of adult rat hepatocytes. Induction of glucose-6-phosphate dehydrogenase and suppression of malic enzyme and lipogenesis. $J$ Biol Chem 258, 12355-12360.

45. Ma XJ, Salati LM, Ash SE, et al. (1990) Nutritional regulation and tissue-specific expression of the malic enzyme gene in the chicken. Transcriptional control and chromatin structure. J Biol Chem 265, 18435-18441.

46. Katsurada A, Iritani N, Fukuda H, et al. (1987) Influence of diet on the transcriptional and post-transcriptional regulation of malic enzyme induction in the rat liver. Eur J Biochem 168, 487-491.

47. Goodridge AG, Crish JF, Hillgartner FB, et al. (1989) Nutritional and hormonal regulation of the gene for avian malic enzyme. J Nutr 119, 299-308. 